\title{
Relationships between Body Size, Weight and Fecundity of the Endangered Fish Alburnus carinatus Battalgil, 1941 in the Manyas Lake (Turkey)
}

\author{
Gülşah Saç ${ }^{1}$ (D) Özcan Gaygusuz ${ }^{1}$ (D)
}

Cite this article as: Saç, G., Gaygusuz, Ö. (2020). Relationships between body size, weight and fecundity of the endangered fish Alburnus carinatus Battalgil, 1941 in the Manyas Lake (Turkey). Aquatic Sciences and Engineering, 35(1), 27-30.

ORCID IDs of the authors: G.S. 0000-0001-9988-1116; Ö.G. 0000-0001-6861-6221

'Istanbul University, Faculty of Aquatic Sciences, Department of Marine and Freshwater Resources Management, 34134, Laleli, Istanbul, Turkey

Submitted: 02.08.2019

Revision Requested:

24.11.2019

Last Revision Received:

01.12.2019

Accepted:

12.12.2019

Online published:

27.12.2019

Correspondence:

Gülşah Saç

E-mail:

gulsahsac@gmail.com

(C) Copyright 2020 by Aquatic Sciences and Engineering Available online at

https://dergipark.org.tr/ase

\begin{abstract}
Alburnus carinatus Battalgil, 1941 is an endangered fish species, which has a narrow distribution range in two shallow lake basins in northwest Anatolia. The present study aimed to describe the reproductive potential of this endemic fish with the relationships between body size, weight, and fecundity. A total of 101 female A. carinatus were captured from the Manyas Lake between January and June 2019. The standard length and body weight of these samples varied between $8.1-$ $15.0 \mathrm{~cm}$ and $9.38-65.45 \mathrm{~g}$, respectively. The length-weight relationship of the female $A$. carinatus was calculated as $\mathrm{W}=0.020 \times \mathrm{SL}^{2.959}\left(\mathrm{r}^{2}=0.866\right)$ with isometric growth. Absolute fecundity ranged from 1512 eggs $(8.1 \mathrm{~cm} \mathrm{SL})$ to 3203 eggs (10.3 cm SL) with a mean of 2281 eggs (SD = 415.2). Fecundity-length relationship was $F=5.86 \times S^{2.67}\left(r^{2}=0.702\right)$ and the fecundity-length relationship was $F=476.6+116.5 \times \mathrm{L}\left(r^{2}=0.688\right)$. Mean relative fecundity was calculated as $244 \mathrm{eggs}_{\mathrm{cm}} \mathrm{cm}^{-1}(\mathrm{SD}$ $=34.1$ ) (ranged from 179.8 to 310.9 eggs. $\mathrm{cm}^{-1}$ ) and $148 \mathrm{eggs.g^{-1 }}(\mathrm{SD}=14.9)$ (ranged from 115.1 to 171.8 eggs. e $^{-1}$ ).
\end{abstract}

Keywords: Endemism, shallow lake, length-weight relationship, spawning potential, Anatolia

\section{INTRODUCTION}

Until recently, most of the Turkish shemayas (Alburnus spp.) have been described as subspecies of Chalcalburnus chalcoides, however recent detailed studies on the morphological and molecular features of this genus have revealed that descriptions of some species were incorrect and that the species diversity for Turkish shemayas was high (Özuluğ \& Freyhof, 2007a). Turkey - particularly Anatolia - is the center of biodiversity and endemism of the genus Alburnus and a total of 27 species were recognized with recent studies (Krupp, 1992; Kottelat \& Freyhof, 2007; Özuluğ \& Freyhof, 2007a; Özuluğ \& Freyhof, 2007b; Elp, Şen, \& Özuluğ, 2015; Özuluğ, Geiger, \& Freyhof, 2018; Freyhof \& Turan, 2019; Fricke, Eschmeyer, \& Van der Laan, 2019). One of these newly described species, Alburnus carinatus Battalgil, 1941 is a fish en- demic to northwest Anatolia living in the Manyas and Uluabat lake basins. According to the IUCN Red List (2019), this species is classified as Endangered due to habitat restriction. Additionally, the Manyas and Uluabat lakes, where this endemic fish live, are under heavy environmental pressure from pollution and water extraction (Özuluğ \& Freyhof, 2007a; Dorak, Köker, Sağlam, Akçaalan, \& Albay, 2017). Invasive Carassius gibelio (Bloch, 1782) reported from the Manyas Lake in the 2000s (Emiroğlu, Arslan, Malkoç, Koç, \& Çiçek, 2008) can be considered to be another potential threat for A. carinatus in the lake.

Bagenal \& Tesch (1978) have defined the fecundity as the seasonal spawning potential or as the number of eggs ripening during the spawning period of a female. Fecundity is generally calculated for commercial fish species due to 
their importance in assessing their economic potential. In terms of ecosystem management, however, the fecundity of non-commercial fish species is highly critical for the assessment of the ecological roles of these species. The survival of endemic $A$. carinatus in the Manyas Lake, where environmental pressures are intense, is critical. The present study aims to reveal the reproductive potential of this endangered fish with the relationships between body size, weight, and fecundity. Additionally, this study will contribute to the gap in knowledge of the length-weight relationship and some reproductive characteristics of this fish species.

\section{MATERIAL And METHOD}

\section{Study area}

The Manyas Lake located in the western part of Anatolia is a shallow (mean depth $=1.7 \mathrm{~m}$, maximum depth $=3.4 \mathrm{~m}$ ) and a turbid lake (Albay \& Akçaalan, 2003; Dorak et al., 2017). The main water sources that feed the lake are the Sığırcı, Köydere, Kocaçay, Karadere and Mürvetler streams as well as annual rainfall (Figure 1). The lake was designated as a Ramsar Site in 1994 in terms of being on the migration routes of some bird species and used by these birds as a nesting and shelter area (Yeniyurt \& Hemmani, 2011).

\section{Sampling and data analysis}

Fish samples were captured by a fisherman in the Manyas Lake between January and June 2019. For fishing, cast nets $(10 \mathrm{~mm}$ mesh size) were used in the northeast shorelines of the lake. The captured samples were immediately transferred to the Laboratory of Istanbul University Faculty of Aquatic Sciences Department Freshwater Resources and Management with cold conditions and then stored at $-18^{\circ} \mathrm{C}$ until the investigations. The fish samples were measured for standard length (SL), fork length (FL) and total length $(T L)$ to the nearest $0.1 \mathrm{~cm}$ and weighed for total body weight $(\mathrm{W})$ on a digital balance with a $0.01 \mathrm{~g}$ accuracy. Length-length transformations (FL vs. TL; SL vs. TL; SL vs. FL) in the fish were calculated using linear regression analysis to be useful in comparing the results of different studies, which will use different length measures.
The length-weight relationship (LWR) was calculated using the equation: $W=a L^{b}$, where $W$ is the total weight $(g), L$ is the standard length $(\mathrm{cm}), a$ and $b$ are regression parameters (Le Cren 1951; Froese, 2006). The equation $\left(W=a L^{b}\right)$ was converted into the natural logarithmic form ( $\mathrm{nW}=\ln a+b \times \operatorname{lnL})$, and parameters a (regression intercept) and $b$ (slope) were calculated by the regression analysis (King, 2007). To determine the growth type (isometry or allometry) of the species, ninety-five percent confidence limits $(95 \% \mathrm{Cl})$ of parameter $b$ was estimated by the equation: $95 \% \mathrm{Cl}=\mathrm{x} \pm\left(\mathrm{t}_{0.05} \times \mathrm{SE}\right)(\mathrm{x}$ : $b$; t: table value of $t$ (t-test at $95 \%$ confidence)); SE: standard error value of b) (King, 2007).

The gonads were removed and weighed to the nearest $0.0001 \mathrm{~g}$ (Precisa XB 220A). For the estimation of absolute fecundity, the gravimetric method was used: sub-samples of approximately $1 \mathrm{~g}$ were taken from 3 different parts of the ovaries (the anterior, medial and posterior parts) and the number of eggs in the sub-samples was multiplied by the weight of the ovary using the following equation; $F=$ number of eggs in the sub-samples $\times$ gonad weight / sub-sample weight (Le Cren, 1951). Relative fecundity (RF) was calculated as the ratio between absolute fecundity $(F)$ and body length and weight (SL and W). The relationships between fecundity and fish length were estimated by exponential regression analysis $\left(F=a L^{b}\right)$ and the relationships between fecundity and fish weight were estimated by linear regression analysis $(F=a+b \times L$; where $F$ is fecundity, $L$ is the standard length $(\mathrm{cm}), a$ is the regression constant, and $b$ is the regression coefficient).

\section{RESULT AND DISCUSSION}

A total of 109 A. carinatus specimens (101 females and 8 males) were captured from the Manyas Lake. The standard length and body weight of the specimens varied between $8.1-15.0 \mathrm{~cm}$ and 9.38-65.45 $\mathrm{g}$ for females and 8.0-11.8 cm and 9.80-32.03 $\mathrm{g}$ for males, respectively. As the individual numbers of the males were quite low, they were not used in the following calculations. The length-length relationships of the female fish specimens were

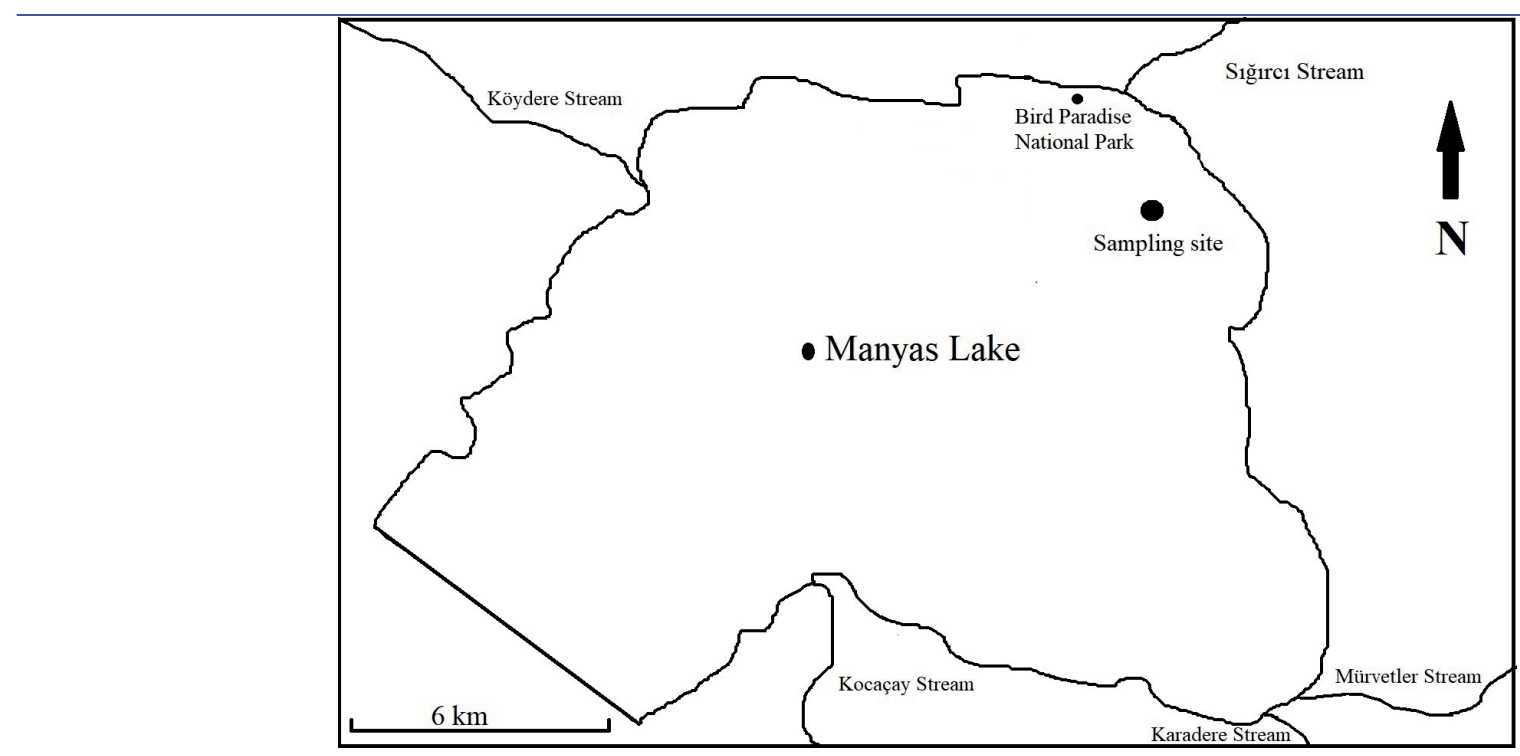

Figure 1. Sampling site in the Manyas Lake. 
calculated as follows; $F L=0.900 \times T L-0.019 \quad\left(r^{2}=0.986\right)$, $\mathrm{SL}=0.078 \times \mathrm{TL}-0.010\left(r^{2}=0.977\right)$ and $\mathrm{SL}=0.868 \times \mathrm{FL}+0.038\left(r^{2}=0.985\right)$.

The length-weight relationship of female $A$. carinatus was calculated as $W=0.020 \times S L^{2.959}\left(r^{2}=0.866\right)$ (Figure 2). In terms of growth type, $95 \% \mathrm{Cl}$ of parameter b was calculated between 2.84 and 3.08 and the results showed that the growth type of the population was isometric $(b=3)$.

Froese (2006) indicated that the range of the parameter b usually encountered in fishes was within the expected range of $2.5-3.5$. In this study, the value of $b$ for female $A$. carinatus was within this expected range and therefore, the result can be used as valid data for the FishBase database. Because there is no other study on the length-weight relationship of this endemic fish, a comparison could not be made.

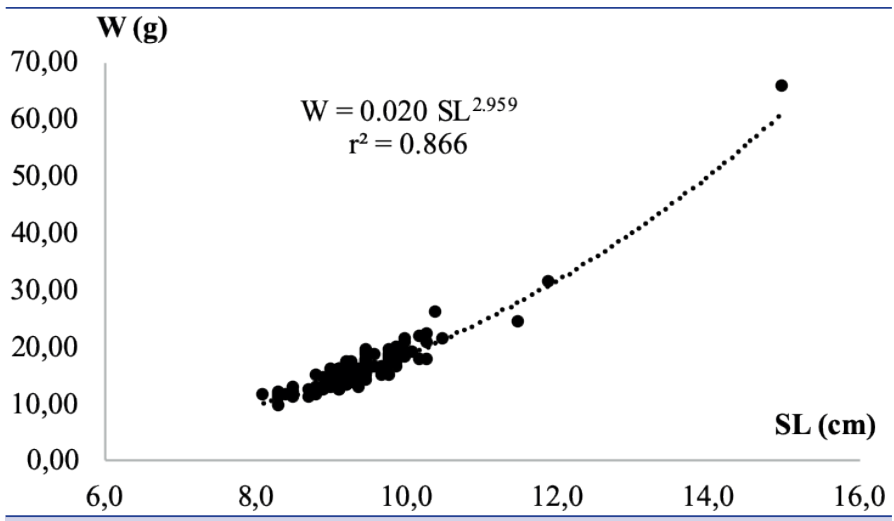

Figure 2. Diagram of the length-weight relationship of $A$. carinatus living in the Manyas Lake.

For estimating the fecundity of the species, a total of 47 individuals captured between April and June (2019) were used. The average absolute fecundity in mature females was 2281 eggs (SD = 415.2), ranging from 1512 eggs $(8.1 \mathrm{~cm} \mathrm{SL})$ to 3203 eggs $(10.3 \mathrm{~cm}$ $\mathrm{SL})$. The relationship between body length, weight, and absolute fecundity were positively correlated; the fecundity-length relationship was $F=5.86 \times S L^{2.67}\left(r^{2}=0.702\right)$ and the fecundity-length relationship was $F=476.6+116.5 \times W\left(r^{2}=0.688\right)$ (Figure 3,4$)$.

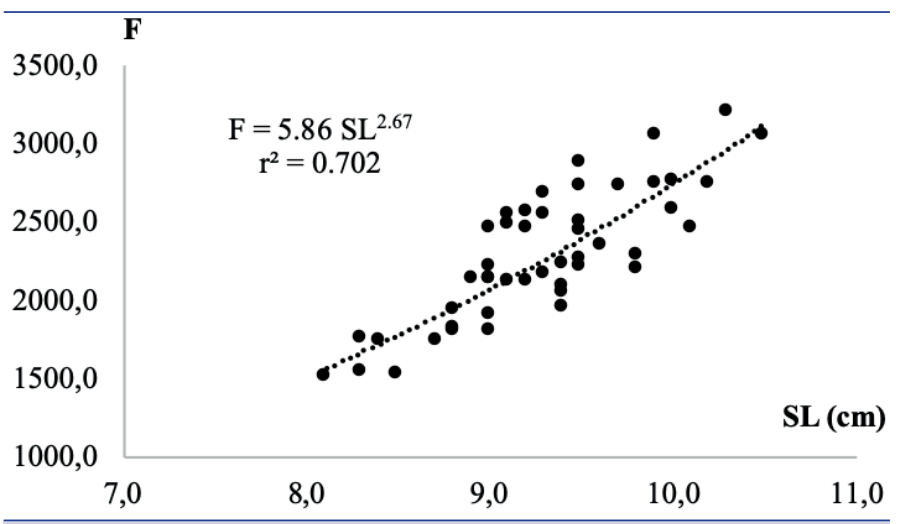

Figure 3. Diagram of the fish length-fecundity relationships of A. carinatus living in the Manyas Lake.

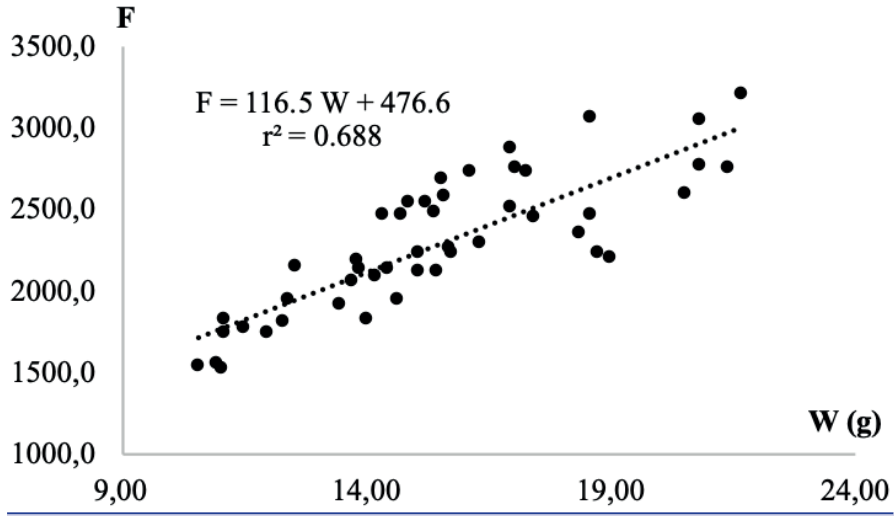

Figure 4. Diagram of the fish weight-fecundity relationships of $A$. carinatus living in the Manyas Lake.

Mean relative fecundity was calculated as 244 eggs. $\mathrm{cm}^{-1}$ (SD = 34.1 ) (ranged from 179.8 to 310.9 eggs. $\mathrm{cm}^{-1}$ ) and 148 eggs. ${ }^{-1}$ $(\mathrm{SD}=14.9)$ (ranged from 115.1 to 171.8 eggs. $\left.^{-1}\right)$.

Fecundity is affected by several factors such as fish size, weight, age, and life-history traits of fishes as well as the environmental conditions such as food supply, population density, and temperature (Ünlü \& Balcı, 1993; Ali \& Wootton, 1999). In this study, a positive correlation between fecundity and fish length and fish weight was found: fecundity increased with the increase of fish length and weight and the larger fish produced more eggs. While the coefficient of the determination $\left(r^{2}\right)$ was above 0.7 in the fish length-fecundity relationship $\left(r^{2}=0.702\right)$, it was calculated as 6.88 for the fish weight-fecundity relationship. This small difference might be related to the narrow size/weight range of the fish samples.

There are many factors threatening the presence of endemic $A$. carinatus in the Manyas Lake. The agricultural waste of cultivated areas, livestock activities, poultry farms around the lake and the streams are the main pollution sources of the lake and the water quality was identified as eutrophic due to its nutrient concentrations and biological characteristics (Albay \& Akçaalan, 2003; Dorak et al., 2017). Invasive C. gibelio, which was detected in the 2000s in the lake (Emiroğlu et al., 2018) and is accepted as a sperm parasite (Perdikaris et al., 2012), may threaten A. carinatus with food and habitat competition. Carnivorous fish species (Esox lucius Linnaeus, 1758 and Silurus glanis Linnaeus, 1758) living in the lake, waterfowls, which are permanently or periodically found in the Lake basin, and local fishermen can create prey pressure on this fish. Additionally, the recently constructed Manyas Dam is thought to be another threat for A. carinatus, which migrates to the streams for reproduction.

The conservation status of $A$. carinatus has been assessed as Endangered because its area of occupancy (AOO) is estimated to be less than $300 \mathrm{~km}^{2}$. However, there is no action plan for the conservation of this special fish. In order to prevent the extinction of this endemic fish and to ensure the continuity of the population in its limited distribution areas (Manyas and Uluabat lake basins), its bio-ecological characteristics and habitat requirements should be identified in detail. It is highly important to 
avoid threats such as pollution, invasive fish introduction, overfishing, and habitat degradation. In addition, local people and fishermen should be informed about the importance of this endangered species.

\section{CONCLUSIONS}

In conclusion, this study has provided some baseline information on the length-weight relationship and fecundity features of endangered $A$. carinatus. Since there is no published information about these features of this endemic fish, the results are expected to be useful for future studies.

Conflict of Interests: The authors declare that for this article they have no actual, potential or perceived conflict of interests.

Acknowledgements: This study was supported within the scope of the TÜBITAK-1003 Project entitled "Development of an Integrated Ecosystem Modelling Based Decision Support System for Management of Manyas Lake Watershed" (No: 116Y406).

\section{REFERENCES}

Albay, M. \& Akçaalan, R. (2003). Comparative study of periphyton colonisation on common reed (Phragmites australis) and artificial substrate in a shallow lake, Manyas, Turkey. Hydrobiologia 506-509, 531-540. [CrossRef]

Ali, M. \& Wootton, R. J. (1999). Effect of variable food levels on reproductive performance of breeding female three-spined sticklebacks. Journal of Fish Biology, 55, 1040-1053. [CrossRef]

Bagenal, T. B. \& Tesch, F. W. (1978). Methods for assessment of Fish Production in Fresh Waters, IBP Handbook No. 3 (3rd ed.). Timothy Bagenal (Ed.). Blackwell Scientific Publications, Oxford, London, Chapter 5. 101-136 pp.

Dorak, Z., Köker, L., Sağlam, O., Akçaalan, R. \& Albay, M., 2017. Determination of zooplankton community structure, biomass and trophic state of a shallow turbid lake. Fresenius Environmental Bulletin, 26 (1A), 834-845

Emiroğlu, Ö., Arslan, N., Malkoç, S., Koç, B. \& Çiçek, A. (2008). Determination of cadmium levels in lake water, sediment, meiobenthos (Chironomidae) and three fish species from Lake Uluabat (a Ramsar site in Turkey). EIFAC Occasional Paper, 44, 263.

Elp M., Şen F. \& Özuluğ M. (2015). Alburnus selcuklui, a new species of Cyprinid fish from East Anatolia, Turkey (Teleostei: Cyprinidae). Turkish Journal of Fisheries and Aquatic Sciences, 15, 181-186. [CrossRef]
Freyhof, J. \& Turan, D. (2019). Alburnus magnificus, a new species of bleak from the Orontes River drainage (Teleostei: Leuciscidae). Zootaxa, 4559 (2), 373-383. [CrossRef]

Fricke, R., Eschmeyer, W. N. \& Van der Laan, R. (eds) (2019). Eschmeyer's Catalog of Fishes: Genera, Species, References. (http:// researcharchive.calacademy.org/research/ichthyology/catalog/ fishcatmain.asp). Electronic version accessed 25 July 2019.

Froese, R. (2006). Cube law, condition factor, weight-length relationships: History, meta-analysis and recommendations. Journal of Applied Ichthyology, 22, 241-253. [CrossRef]

IUCN, 2019. The IUCN Red List of Threatened Species. Version 2019-2. $<$ https://www.iucnredlist.org>

King, M. (2007). Fisheries Biology, Assessment and Management, 2nd ed.; Blackwell Scientific Publications: Oxford, UK, p. 381. [CrossRef]

Kottelat M. \& Freyhof J. (2007). Handbook of European freshwater fishes. Berlin, 640 pp.

Krupp F. (1992). Two new species of cyprinid fishes from the Mediterranean coastal drainage basin of Syria (Pisces: Osteichthyes: Cyprinidae). Senckenbergiana Biologica, 72, (1/3), 19-25.

Le Cren, E. D. (1951). The length-weight relationship and seasonal cycle in gonad weight and condition in the perch (Perca fluviatilis). Journal of Animal Ecology, 20, 201-218. [CrossRef]

Özuluğ, M. \& Freyhof, J. (2007a). Rediagnosis of four species of Alburnus from Turkey and description of two new species (Teleostei: Cyprinidae). Ichthyological Exploration of Freshwaters, 18 (3): 233246. [CrossRef]

Özuluğ M. \& Freyhof J. (2007b). Alburnus demiri, a new species of bleak from Western Anatolia, Turkey (Teleostei: Cyprinidae). Ichthyological Exploration of Freshwaters, 18, 307-312.

Özuluğ M., Geiger M. F. \& Freyhof J. (2018). Alburnus goekhani, a new species of bleak from the Anatolian Black Sea basin (Teleostei: Leuciscidae). Zootaxa, 4425 (1), 29-40.

Perdikaris, C., Ergolavou, A., Gouva, E., Nathanailides, C., Chantzaropoulos, A. \& Paschos, I. (2012). Carassius gibelio in Greece: the dominant naturalised invader of freshwaters. Reviews in Fish Biology and Fisheries, 22, 17-27. [CrossRef]

Ünlü, E. \& Balcı, K. (1993). Observation on the reproduction of Leuciscus cephalus orientalis (Cyprinidae) in Savur stream (Turkey). Cybium, 17 (3), 241-250.

Yeniyurt, C. \& Hemmami, M. (2011). Ramsar sites of Turkey, Doğa Derneği Publications, Ankara, Turkey. 